\author{
Henning Nфlke*
}

\title{
Informationsstruktur \\ - med fokus på fokus
}

\section{Introduktion 1}

Alle tekster strukturerer deres informationer. Dertil bruges kapitler, afsnit og sætninger. Helt ned på sætningsniveau foregår en sådan strukturering, og derved bliver informationsstrukturering et næsten syntaktisk fænomen. Det er informationsstrukturering på sætningsniveau, der er emnet for denne artikel. Der er fx stor forskel på, om jeg siger Peter elsker Marie eller Marie elsker Peter. I det første tilfælde siger jeg noget om Peter, i det andet tilfælde snarere noget om Marie. Således kan ordstilling og de syntaktiske funktioner subjekt og objekt hjælpe med til at strukturere informationen på en særlig måde. Vi skal se, at der er et subtilt spil mellem på den ene side de ord og den form, man vælger til sine sætninger, og på den anden side den strukturering af informationen, disse kommunikerer.

Hvad mere er, varierer dette forhold fra sprog til sprog. Der er visse regler, man genfinder i flere sprog, medens der er andre, der er forskellige selv mellem nært beslægtede sprog. Derfor er et studium af informationsstrukturering på sætningsniveau væsentligt også for indlæringen og forståelsen af fremmedsprog. I denne artikel vil der især blive tale om at analysere informationsstrukturen på fransk; men der vil også blive givet eksempler fra andre sprog, og det er mit håb, at læseren selv vil prøve at sammenligne de sprog, han/hun kender med henblik på at afsløre forskelle og ligheder.

1 Denne artikel er ment som en introduktionsartikel til studiet af informationsstrukturer på sætnings/ytringsniveau. Den indeholder nødvendigvis noget vanskeligt stof, som jeg prøver at gøre lidt lettere tilgængeligt. På den anden side kan læseren også finde visse nye tanker, og jeg håber således, at også den professionelle lingvist vil kunne finde noget af interesse. Artiklen bygger især på Nølke (1994).

* Henning Nolke

Department of French

The Aarhus School of Business

Fuglesangs Allé 4

8210 Aarhus V(DK) 
Informationsstruktur er et ret komplekst fænomen, og det er ikke muligt at komme hele vejen rundt i en kort artikel. Jeg vil derfor nøjes med at skitsere, hvilke elementer informationsstrukturen er bygget op af, for derpå at koncentrere mig om et af disse, nemlig begrebet fokus, som jeg håber at have noget nyt at sige om. Til sidst vil jeg så kort vise, hvorledes alle de forskellige aspekter kan samles til en "informationscocktail" inden for rammerne af den enkelte sætning. Inden vi går i gang, er det dog nødvendigt mere generelt at se på forholdet mellem sprogets form og betydningsdannelsen og dermed også dets evne til at formidle information.

\section{Informationsstruktur}

Den information, en sætning kommunikerer, er en væsentlig del af sætningens samlede betydning. Det vi skal beskæftige os med, er altså et fors $\emptyset \mathrm{g}$ på at beskrive, hvilke regler eller principper der forbinder selve den sproglige form med dens betydning. For at kunne gøre dette videnskabeligt er vi nødt til at diskutere en smule videnskabsteori.

\section{Fra form til betydning: Nogle grundbegreber}

Allerførst må vi gøre os klart, hvilken status de sproglige data har. For overhovedet at kunne analysere forholdet mellem form og betydning, må vi selvfølgelig først have nogle former og nogle betydninger. Med andre ord må vi have nogle sætninger med tilhørende betydninger. $\mathrm{Nu}$ er sådanne jo imidlertid ikke givne fra naturens hånd. Vi bestemmer det har vi lært i skolen -, hvad der er en sætning, og vel også, hvorledes den er skruet sammen (hvilke ord den består af, hvorledes dens syntaks er osv.). Derpå tillægger vi så sætningen en betydning. Allerede her bliver det vanskeligere. Vi er ikke altid helt sikre på, hvad en sætning betyder, især ikke hvis vi får den præsenteret ude af sammenhæng; og selv om vi kender hele dens kontekst, kan vi være i tvivl. Tænk blot på, hvor tit to mennesker i samme situation får noget helt forskelligt ud af den samme sætning. Vore sproglige data er altså på ingen måde rå eller umiddelbart naturgivne; de er resultatet af nogle mere eller mindre ubevidste analyser, vi har foretaget. I denne forstand skaber vi selv data, og først når vi har gjort det, kan vi begynde på den teoretiske analyse af dem. Datas status i forhold til teori er illustreret i nedenstående skema: 
(1)

Figur (1) illustrerer, at virkeligheden ikke kan blive direkte genstand for vore undersøgelser. Først må vi - ved hjælp af, hvad man kan kalde "de eksterne hypoteser" (se fx Ducrot 1980: 19-25) - etablere data. Først dernæst kan vi udvikle en teori, der altså er bygget op af (teori)interne hypoteser. Når vi fx analyserer en given sætning, må vi først være enige om, hvilken form denne sætning har, og hvad den betyder. Det er meget væsentligt, så vidt det overhovedet er muligt, ikke at blande de eksterne og de interne hypoteser sammen. I princippet bør alle data etableres helt uafhængigt af den teori, man derpå anvender for at forklare data, da teorien ellers mister en væsentlig del af sit forklaringspotentiale. At det næppe er muligt at opretholde dette skel i praksis, er en anden sag, der i øvrigt har været genstand for mange videnskabsteoretiske diskussioner. Det viser sig nemlig, at der i alle videnskaber - og måske særlig tydeligt i humaniora - er en uundgåelig sammenhæng mellem data og teori. Man ser altid verden gennem nogle bestemte teoretiske briller. I det følgende vil jeg imidlertid lade, som om dette epistemologiske problem ikke eksisterer, og altså antage, at vi a priori er enige om, at de sætninger, vi studerer, har den form og betydning, jeg påstår.

Som det fremgår af figur (1), opererer vi med tre betydningsbegreber: (virkelig) interpretation, som er individuel og altså utilgængelig for generelle lingvistiske undersøgelser, betydning, der defineres som den semantiske værdi, lingvisten tillægger det studerede sproglige udtryk, og signifikation, der er den abstrakte semantiske værdi, teorien udvikler ud fra nogle teoriinterne regler, og som på principiel vis skal kunne forklare betydningen. 
I den teoretiske tilgang, jeg vil foreslå til behandling af informationsstrukturering, kan disse tre begreber defineres på følgende måde:

Signifikation (eller den "sproglige betydning") er et sæt af instruktioner, der genereres af teorien.

Betydning er den semantiske værdi, lingvisten tillægger teksten, og her mere specielt ytringen.

Interpretation er den semantiske værdi, den individuelle modtager tillægger ytringen.

Disse grundbegreber gør det muligt at opstille en model for betydningstilskrivningen:

- Signifikationen producerer en mængde parametre (eller variabler) med instruktioner for, hvorledes disse skal instancieres.

- Konteksten bidrager med elementer til denne instanciering, som er en del af interpretationsprocessen.

- Selve interpretationsprocessen styres af interpretationsstrategier, der opererer inden for de grænser, der er sat af signifikationen.

Ideelt set bør lingvisten forudse alle virtuelle interpretationer af de ytringer, han studerer. Dette er naturligvis umuligt; men han kan indføre en slags "normallæser/-hører" og en "normalsituation". Med andre ord kan han tilstræbe, at hans teori kan forudsige, hvilken interpretation ytringerne får alt andet lige. Denne interpretation kalder vi ytringens defaultlæsning. Defaultlæsningen bestemmes af det sproglige materiale, men kan altså ændres alt efter den sammenhæng, dette ytres i. Afhængigt af det sproglige materiale, kan modtager mere eller mindre let nå frem til en anden interpretation:

(2) a. Jeg kommer tilbage.

b. Jeg lover dig at komme tilbage.

I a. er defaultlæsningen formentlig en ren og skær hævdelse eller konstatering, men alt efter situationen kan den reelle interpretation let være fx et løfte eller en trussel ${ }^{2}$. I b. derimod skal der en helt speciel kontekst til at ændre defaultlæsningen, som her er et løfte. En defaultlæsning kan altså være mere eller mindre stærk. Den kan også være mere eller mindre præcis som følgende eksempler illustrerer:

2 Dette gælder såvel for den interpretation, afsender intenderer, som for den, modtager udfører. At interpretationen af (2a) er så afhængig af hele ytringssituationen, forklarer også, at afsenders og modtagers interpretation ofte kan afvige fra hinanden $i$ sådanne tilfælde. 
(3) a. Franskmændene stemmer på højrepartierne denne gang.

b. Alle franskmændene stemmer på højrepartierne denne gang.

Både franskmoendene og alle franskmoendene har som defaultlæsning, at det drejer sig om dem alle; men medens vi kun betragter b. som sand, hvis det er så godt som hundrede procent af franskmændene, der stemmer til højre, kan vi sagtens ytre a., også selv om det fx kun drejer sig om $70 \%$.

\subsection{Informationsformidling}

Lad os først forsøge at præcisere, hvad vi vil forstå ved "information". Intuitivt er en teksts information, det den siger om verden uden for teksten. Vi kan sige, at enhver tekst - hvad enten den er mundtlig eller skriftlig - har et (propositionelt) indhold, som er bygget op af udsagn (i denne terms logiske forstand). Tekstens indhold er altså en slags billede af virkeligheden, sådan som denne opfattes af afsender. Men indholdet kommunikeres altid gennem enkelte sproghandlinger, som pr. definition har en afsender og en modtager, og som oftest ledsages af andre sproghandlinger. Drejer det sig om fremsættende sproghandlinger, som jeg vil koncentrere mig om i denne artikel, tager afsender en vis stilling til virkeligheden; han siger (hævder, påstår, ...), at den er sådan og sådan. Når afsender således taler om virkeligheden, kommunikerer han information til modtager. Informationsbegrebet er dermed uløseligt forbundet med kommunikationsbegrebet og med tilstedeværelsen af afsender og modtager i teksten. Man kan sige, at formålet med de assertive sproghandlinger er at ændre modtagers opfattelse af verden. Dette kan præciseres. Både afsender og modtager har et "trosunivers" vedrørende, hvordan verden ser ud, hvad de andre tror osv. Informationen tjener typisk til at modificere dette trosunivers. Hvis afsender fx ytrer:

(4) Peter er i Paris.

tilføjer han denne information angående Paris til modtagers trosunivers.

Informationen i (4) præsenteres, som om den ikke eksisterede i modtagers trosunivers forud for ytringen. Den præsenteres som ny information. Mere præcist er det, der præsenteres som nyt, at egenskaben "er i Paris" passer på Peter. For at kunne ændre modtagers trosunivers, må man nemlig først lokalisere det, man vil ændre. Med andre ord må 
man først angive informationens tema. Først når tema er udpeget, kan man knytte en oplysning til tema. Denne oplysning kan så bestå i tilknytningen af en ny egenskab, i etablering af nye bånd til andre udsagn i modtagers trosunivers, $i$ en sletning af sådanne udsagn m.m.

Både udpegning af tema og præsentationen af den egentlige information kan formidles på forskellig vis. Der findes adskillige formidlingsmodi. Informationen kan ikke blot, som vi har set det, være hævdet (ny); den kan også være præsupponeret, den kan præsenteres som mere eller mindre væsentlig, den kan være implicit eller eksplicit osv. Dertil kommer, at informationen også kan være struktureret på mange forskellige måder. Naturligvis bestemmes den endelige form i interpretationsprocessen og er således modtagerafhængig; men i et fors $\varnothing \mathrm{g}$ på at sikre kommunikationen vil afsender altid tilstræbe at styre interpretationen mest muligt. Hertil råder han over en række sproglige midler. Fx spiller ordstillingen i (4) en afg ørende rolle for udpegningen af tema, og tilstedeværelsen af verbet vare afføder den enkle læsning af (4) som en hævdelse. Det fremgår tydeligt, hvis man sammenligner (4) med (5), hvor vi har erstattet verbet vare med verbet blive:

(5) Peter bliver i Paris

(5) formidler samme information som (4), nemlig at Peter er i Paris; i

(5) er denne information imidlertid ikke præsenteret som ny, men derimod som præsupponeret. Det nye, der hævdes i (5) er, at Peter vil være i Paris et stykke tid endnu.

Informationsformidlingen sker altså gennem ytringsprocessen. Denne bygger på to primitive ytringsoperationer: monstration og veridiktion. Ved veridiktion forstås enhver ytringsoperation, der involverer sandhedsbegrebet. Hvis afsender fx ytrer:

(6) Jorden er rund.

påstår han, at det er sandt at sige om jorden, at den er rund. Sandhed spiller også en afgørende rolle i (7):

(7) Er jorden rund?

hvor afsender forhører sig om sandhedsværdien af propositionen 'jorden er rund'. En veridiktion præsenterer altid indholdet som værende mulig genstand for debat. Derfor kan et indhold, der er underkastet veridiktion, benægtes, betvivles osv. Selve påstanden (i (6)) og selve spørgsmålet (i (7)), kort sagt selve veridiktionen, er imidlertid ikke 
præsenteret som drejende sig om sandhed. Det ville være nonsens at tale om, at selve spørgehandlingen er sand eller falsk, ligesom det ikke giver nogen mening at tale om, at den er mere eller mindre sandsynlig. Spørgehandlingen er der bare så at sige. Den er, siger vi, resultat af den elementære ytringsoperation monstration ${ }^{3}$.

Det er ikke blot de forskellige sproghandlinger, der vises snarere end de hævdes; også visse ord- og ledtyper afslører denne specielle egenskab. Det klassiske eksempel er interjektionerne, der viser følelser o.l. I en ytring som fx $a v$ ! er interjektionen underkastet monstration, hvilket bl.a. viser sig i, at den ikke kan nægtes; det ville være absurd at sige ikke $a v$ !. Men også mange andre størrelser vises i denne forstand. For eksempel kan sætningsadverbialer aldrig underkastes veridiktion. De er altid vist. Det er derfor, man ikke kan sige Peter er ikke heldigvis kommet hjem eller Det er heldigvis Peter er kommet hjem. Kun det, der er præsenteret ved hjælp af ytringsoperationen veridiktion, kan nægtes eller sættes i relief ved hjælp af en sætningskløvning.

I sidste afsnit vender jeg tilbage til forholdet mellem de fundamentale ytringsoperationer og informationsstruktureringen.

\subsection{Informationsstruktur: Begrebsforvirring}

Det er en fundamental egenskab ved mennesket, at det strukturerer alt, hvad det opfatter og erfarer, i et baggrunds- og et forgrundsplan. Alt ses i en kontekst. Lige siden Aristoteles har først filosofferne og siden lingvisterne fors $\emptyset \mathrm{gt}$ at afdække denne strukturerings sproglige manifestation; og man har fundet den helt ned på ytringsniveauet. Faktisk ser det ud til, at ytringen altid struktureres i et baggrunds- og et forgrundsplan. Hertil er alle enige. Men fra det $\varnothing$ jeblik, hvor det drejer sig om at præcisere, hvad denne tvedeling egentlig består i, og hvorledes den udmønter sig rent sprogligt, er der næsten lige så mange opfattelser, som der er sprogforskere.

Blandt de begreber, man har taget tilflugt til for at beskrive fænomenet, er de mest udbredte utvivlsomt termparret tema/rhema, som er

3 Det er denne betragtning, der førte Wittgenstein til at skelne mellem, hvad der er sagt, og hvad der (blot) er vist. Wittgenstein påviste, at disse to operationer altid er adskilte, for "det der kan vises, kan ikke siges" (Wittgenstein 1961: § 4.1212). Termerne veridiktion og monstration er indført af de analytiske filosoffer (jf. Récanati 1979: kap. 7-8). Den anvendelse, jeg her gør af dem, er foreslået første gang af Hans Kronning $(1990 ; 1993)$. 
direkte nedarvet fra Aristoteles, der taler om $\vartheta \varepsilon \mu \alpha \alpha$ og $\rho \eta \mu \alpha^{4}$. Men er der end en vis konsensus mht. termerne, så er dette langt fra tilfældet mht. de definitioner, der er foreslået. Der hersker faktisk en betragtelig begrebsforvirring på området, hvilket tilsyneladende hænger sammen med, at ytringen på én og samme tid kan formidle flere binære strukturer, som ofte, men langt fra altid, falder sammen. I nyere sprogvidenskabelig litteratur finder man (mindst) følgende ti mere eller mindre forskellige definitioner, sommetider i kombination:

(8) Tema-rhema svarer til:
a. Ytringens første segment
/ Resten
b. Det man taler om
/ Det man siger om det
c. Det præsupponerede
/ Det fremsatte (ponerede)
d. Trykløse segmenter
/ Trykbærende elementer
e. Substrat (basis)
/ Fokus
f. Kendt
/ Ukendt
g. Kontekstuelt bundet
/ Kontekstuelt ubundet
h. Gammel information
/ Ny information
i. Uvæsentlig information
/ Væsentlig information
j. Lille kommunikativ dynamik / Stor kommunik. dynamik

Som det fremgår, etablerer de fire første definitioner klart binære strukturer, medens resten mere og mere nærmer sig ideen om et kontinuum. Definition b. er den klassiske, der går direkte tilbage til de gamle grækere. Tema efter b. svarer også til, hvad nogle kalder psykologisk subjekt. Kært barn har mange navne.

Definitionerne kan placeres i to store klasser. I den første finder man a. og d., der definerer tema-rhema som et rent formelt fænomen på ytringsniveau, og i den anden er alle de andre definitioner, som mere direkte vedrører informationsstruktureringen. Særlig interessante for os er måske strukturerne defineret i a., c., d. og e., idet disse i modsætning til de andre er systematisk markerede i selve det sproglige udtryk ${ }^{5}$. De vedrører i $\emptyset$ vrigt fire forskellige niveauer i sprogbeskrivelsen. Den første er af syntaktisk natur, den anden er logisk (eller pragmatisk), den

4 I moderne tid er det H. Ammann, der har genintroduceret termerne tema og rhema (1925: 2-3).

5 Det gælder også skellet kendt/ukendt for så vidt som de bestemte og ubestemte artikler netop bruges i substantivsyntagmer til at angive, om disses referenter er kendte eller ukendte. Dette aspekt af informationsstruktureringen kommer jeg dog ikke ind på i denne artikel. 
tredje fonetisk og den fjerde er direkte knyttet til ytringssituationen. Det er denne fjerde struktur, jeg vil se nærmere på i det følgende; men i afsnit 3 kommer jeg tilbage til, hvorledes de forskellige strukturer spiller sammen i den konkrete ytring.

\section{Fokus på fokus}

Hvad forstår man i lingvistik ved termerne fokus og den beslægtede term fokalisering (eller fokusering)? Som så mange andre populære termer i lingvistik viser disse sig, selv ved en hurtig analyse, at have et overordentlig vagt indhold. Sprogforskere benytter dem oftest uden at bekymre sig om at definere dem, og de enkelte definitionsfors $\emptyset \mathrm{g}$, man kan finde, er ret så forskellige. Således er fokus for nogle et syntaktisk fænomen (det gælder specielt for de generative grammatikere) og for andre et rent prosodisk (fx Morel 1992: 14). Imidlertid synes hverken en rent syntaktisk eller en rent fonetisk/ prosodisk definition at have synderlig almen interesse for lingvisten. Intuitivt har fokus nemlig med betydning at gøre, og det er interessant at iagttage, at selv de, der foregiver at have en unilateral definition, bygger den på en intuition om fokaliseringens semantiske funktion. Det forekommer da også vanskeligt at forestille sig en formel definition, der ikke er semantisk motiveret; den ville i bedste fald være udtryk for misbrug af terminologi.

Når det nu er sådan, forekommer det mest fornuftigt først at forsøge at indkredse fokaliseringens semantiske funktion. Undersøger man dette problem nærmere, afslører der sig en vis regelmæssighed bag de $\mathrm{i}$ $\emptyset$ vrigt ret så forskellige formelle definitioner; en regelmæssighed, der også synes at ligge bag de uformelle og intuitive anvendelser af termerne. Derfor må en begrebsanalyse være en forudsætning for udviklingen af en teori om fokus og fokalisering.

\subsection{Begrebsanalyse}

Der er enighed om, at fokus er et segment, der på en eller anden måde er understreget - "fokaliseret" - af afsender, og som således formidler en "væsentlig information". Problemet er altså at præcisere, hvad man i denne forbindelse kan forstå ved "væsentlig information". I hvilken forstand er denne information væsentlig? Den oprindelige betydning af "fokalisering" er "koncentration", og i tekniske sammenhænge har termen fået betydningen "koncentration på et punkt" (fokus). Sådan bru- 
ger fx fotograferne ordet. Den præteoretiske anvendelse af termen inden for lingvistik bygger på en intuitiv tilpasning af dette billede. "Fokalisere" betyder "sætte i fokus", dvs. "henlede opmærksomheden på". Når man fokaliserer et element i en ytring er det dog ikke bare for at henlede opmærksomheden på elementet, det er snarere for at gøre opmærksom på den særlige rolle det spiller i forhold til andre størrelser i konteksten og specielt i forhold til de andre segmenter i ytringen. Takket være sprogets fundamentale paradigmatiske natur kan man præcisere, at sproglig fokalisering grundlæggende bruges til at præsentere det fokaliserede element som resultatet af et valg truffet inden for et paradigme af lignende elementer. Endvidere foretages valget altid med et særligt formål for øje.

Som en direkte følge af disse betragtninger må fokus opfattes som resultatet af en fokaliseringsproces, der finder sted i selve ytringsøjeblikket, og hvis "afkodning" udgør en nødvendig del af interpretationsprocessen.

Derfor kan fokus karakteriseres ved tre konstituerende og indbyrdes afhængige egenskaber:

Den første er syntagmatisk: Fokus fremstår i ytringen som bestående af en sammenhængende del af den lineære streng. Det kan dreje sig om en række ord, om et enkelt ord eller blot om en del af et ord. Modtager må lokalisere fokus' udstrækning.

Den anden er paradigmatisk: Fokus præsenteres som resultatet af et valg truffet blandt elementerne i et paradigme. Modtager må genetablere dette paradigme.

Den tredje er intentionel: Det paradigmatiske valg er truffet med et særligt formål for øje. Modtager må forstå dette formål.

Denne karakteristik af fokus synes at svare til den opfattelse, de fleste lingvister har af dette fænomen; men det er svært at vide med sikkerhed, for der hersker stor forvirring på området. For nogle hænger fokus, som vi så ovenfor, direkte sammen med intonationen, medens det for andre er mere eller mindre synonymt med rhema (der som nævnt oftest også forbliver udefineret). Man møder fx ofte termen "rhematisering" tilsyneladende brugt synonymt med det, jeg her kalder fokalisering. Det sker endda, at begge termer benyttes, uden at det er klart, hvilken forskel der gøres på dem. 


\subsection{Fokaliseringstyper}

En del af forvirringen omkring fokusbegrebet skyldes utvivlsomt, at man har overset, at der eksisterer flere typer fokus. Først og fremmest den tredje konstituerende egenskab er væsentlig i denne forbindelse. Formålet viser sig nemlig at spille en afgørende rolle både for fokus' måde at komme til udtryk i ytringen på og for vor opfattelse af dets betydning. Med udgangspunkt i den tredje egenskab kan man med fordel etablere en fokustypologi. Lad os se på nogle eksempler! I hver af de følgende ytringer kan man nok blive enige om, at det understregede segment udgør fokus i en defaultlæsning6:

(9) Paul s'est promené dans la forêt.

(10) Paul n'a pas battu le chat avec le bâton.

(11) Venez demain !

(12) Viendras-tu demain!

(13) (Luc est toujours malade), alors que Paul est guéri.

(14) (Pierre ne l'a pas confirmé,) il l'a affirmé.

(15) Même Paul a compris.

(16) C'est la robe blanche que j' aimerais acheter.

Traditionelt taler man om et (simpelt) ytringsfokus i (9) ${ }^{7}$, om fokus for nægtelsen i (10) for imperativen i (11) og for spørgsmålet i (12). I (13) og (14) har vi kontrastfokus ${ }^{8}$, i (15) fokus for adverbiet même og endelig i (16) fokus i sætningskløvningen. Som det fremgår, er der mange forskellige slags foki.

Jeg skal nøjes med her at skelne mellem to hovedkategorier: neutralt fokus og specialfokus. Fokus i de fire første ytringer er af første type, medens vi i (13), (14) og (15) har eksempler på specialfokus. Det sidste eksempel, sætningskløvningen, tilhører i en vis forstand begge klasser; funktionelt ligner det neutralt fokus, og formelt minder det om specialfokus, fordi det er forbundet med en særlig struktur.

Ved simpelt fokus vil jeg nu forstå et fokus, der enten er neutralt eller resultatet af en sætningskløvning. Simpelt fokus er funktionelt karakteriseret ved, at dets eneste formål er at foretage en identifikation. Dette kræver en uddybning. Som følge af sin paradigmatiske funktion

6 Se afsnit 1.1. for en definition af defaultlæsningen.

7 Det er ikke alle lingvister, der overhovedet ser et fokus i (9).

8 Sommetider kaldes fokus i (14) for metalingvistisk fokus. 
har enhver fokalisering en identifikationsfunktion; men i visse tilfælde er dette fokaliseringens eneste formål, og så får vi et simpelt fokus. I andre tilfælde har fokaliseringen også yderligere formål, og vi får specialfokus. I eksempel (15) ovenfor, fx, er det væsentligste formål med at fokalisere Paul at lade forstå, at det i en eller anden forstand var uventet, at (også) han forstod, hvad det drejede sig om. Inden jeg går over til disse ekstra formål, vil jeg se lidt nærmere på, hvad denne identifikationshandling, der altså er knyttet til enhver fokalisering, egentlig består af.

Man kan skelne mellem svag identifikation, som man finder i neutralt fokus, og stærk identifikation, som man finder i kløvningerne. Forskellen er, at den svage identifikation skaber en inferens ${ }^{9}$ mht., hvad der gælder for de andre elementer i paradigmet, medens den stærke identifikation skaber en egentlig logisk implikation (evt. en præsupposition). Lad os se nærmere på denne forskel.

I en hævdelse som (9) tjener fokaliseringen til at identificere et paradigmeelement, hævdelsen er sand for. Derved underforstås, at den ville blive falsk, hvis man erstattede fokus med et andet element fra paradigmet. Når man fokaliserer, at det er i skoven, Poul har gået en tur, er det for at understrege, at det ikke er et andet sted, modtager kunne have troet, han havde været. Denne inferens opstår, fordi det paradigmatiske valg sættes i relief af fokaliseringen. At der imidlertid kun er tale om en inferens og ikke en logisk følge, fremgår af, at den kan forsvinde i en særlig kontekst. Hvis fx dans la forêt fokaliseres i (9), og det samtidig fremgår af sammenhængen, at afsender taler om, hvad der skete i går eftermiddags, kan man udlede, at det drejer sig om en unik begivenhed, og at (9) implicerer (pragmatisk), at fx ytringen Paul s'est promené dans la ville er falsk. Hvis derimod afsender taler om, hvad der skete, da han var på ferie, udelukker (9) ingenlunde muligheden af, at Paul også skulle have gået tur andre steder.

I de tre andre eksempler på neutralt fokus, (10), (11) og (12), er funktionen den samme bortset fra, at identifikationen her kommunikeres via andre - i en vis forstand "markerede" - sproghandlingstyper. Derved føles fokaliseringen også mere markeret og med den de inferenser, den udløser. I (10), hvor man traditionelt (men fejlagtigt, jf. Nølke 1992) taler om fokus for nægtelsen, drejer det sig om at identificere et element

9 Dette er den teoretiske term for en underforståelse. Nogle taler også om supposition i denne forbindelse. 
(avec le bâton), som den tilsvarende ytring uden nægtelse er falsk for. Det er derfor klart, at det underforstås ret så kraftigt, at denne ytring ville være sand for i hvert fald nogle af de andre af paradigmets elementer. I (11) skal ordren udføres i morgen og ikke fx i dag eller i overmorgen, og i (12) spørger afsender, om modtager kommer i morgen, alt imens han underforstår, at han ikke interesserer sig for at vide, om denne skulle komme på et andet tidspunkt.

Medens neutralt fokus altså i alle tilfælde introducerer en svag identifikation, gør noget helt andet sig gældende for sætningskløvningen, som vi har et eksempel på i (16). En central semantisk funktion for denne struktur er nemlig at identificere et element inden for en mængde (et paradigme), hvis eksistens er præsupponeret (jf. Vikner 1972). Ytringen implicerer så (i logisk forstand), at prædikationen er falsk for de andre elementer i denne mængde pga. en kardinalitetspræsupposition, der er knyttet til kløvningen (jf. Nølke 1983: 120). Ytringen i (16) implicerer altså (logisk), at afsender ikke har lyst til at købe nogen af de andre kjoler, hvis eksistens præsupponeres.

\subsection{Sproglig binding og fokusdomæne}

Hidtil har jeg talt om fokus, som om der var en entydig forbindelse mellem en given sætning og det fokus, der tilskrives dens ytring. Da fokus imidlertid er resultat af en (fokaliserings)proces, der finder sted i selve ytringsøjeblikket, må analysen knyttes til ytringsniveauet og ikke direkte til den strukturelle beskrivelse af sætningen. Derfor kan vi i sidste ende kun afgøre, hvad der er fokus for en konkret ytring, dvs. for en ytring i kontekst. Hvis vi ser nærmere på (16), opdager vi da også, at man sagtens kan forestille sig en situation, hvor fokus ville være robe blanche og ikke blot blanche. For eksempel hvis det drejede sig om at vælge mellem forskellige beklædningsstykker og ikke blot mellem nogle kjoler. Med denne anden tænkte situation ser det dog ud til, at vi har udtømt mulighederne. De to nævnte foki synes faktisk at være de eneste, der kan opstå under en ytring af (16), i hvert fald når vi ser bort fra særlige valg af betoning, der - som vi skal se nedenfor - kan introducere specialfokus. Vi kan altså konstatere, at der er grænser for, hvilke fokaliseringer en given sætning kan give anledning til. Fokalisering er med andre ord underkastet strukturelle, ja endda syntaktiske bindinger. I en kløvning skal fokaliseringen således udmøntes inden for den del af sætningen, der befinder sig mellem præsentativet c'est og konjunktionen (her que). 
Denne type binding er ikke forbeholdt kløvninger. Den genfindes i (9), hvor vi jo har et neutralt fokus. I en passende sammenhæng kan fokaliseringen falde på hele strengen promené dans la forêt, fx som svar på et (underforstået) spørgsmål som: «Qu'est-ce qu'il a fait, Paul ?». Det viser sig imidlertid, at fokaliseringen nødvendigvis må ske inden for denne del af sætningen; den kan ikke med normal betoning ramme fx subjekt. I denne forstand er fokus strukturelt bundet (eller markeret) i sådanne eksempler. Sætningsstrukturen angiver, hvilke elementer der kan fokaliseres og med hvilket formål for øje. Den angiver skalaen af mulige fokustyper.

For at tale om dette syntaktiske fænomen indfører jeg den formelle term fokusdomæne. Det drejer sig om et fænomen, der er analogt med det, visse angelsaksiske lingvister kalder "scope of focus". Fokusdomænerne genereres af syntaksen, og den overordnede regel, der styrer forholdet mellem syntaks og fokalisering, er:

(17) Under ytringsprocessen skal en fokalisering finde sted inden for hvert fokusdomæne genereret af syntaksen.

Som følge af denne regel foregår analysen af fokus (foki) i en konkret ytring altid i to tempi:

(i) Fokusdomæne bestemmes ud fra sætningens syntaktiske struktur (det er den "syntaktiske analyse").

(ii) Det aktuelle fokus bestemmes under hensyntagen til den samlede kontekst (det er interpretationsfasen).

En bemærkning trænger sig på her. Det er velkendt, at der findes ytringer uden fokus. Det gælder fx de såkaldte analytiske ytringer (fire er kvadratroden af seksten o.l.). Denne type er imidlertid snarere undtagelsen, der bekræfter reglen, og jeg vil derfor tale om, at den indicerede fokalisering er blokeret i sådanne tilfælde. Såvel teksttype som specielt semantisk indhold kan medføre en sådan "fokaliseringsblokering".

Bortset fra disse særlige strukturer, som jeg ser bort fra i det følgende, kan man vise, at der gælder følgende regel:

(18) Enhver overfladestruktur indeholder nøjagtig ét simpelt fokusdomæne. Det betyder, at enhver ytring indeholder netop ét simpelt fokus.

I en ukompliceret deklarativ sætning som (9) strækker domænet sig fra hovedverbum (det indbefatter altså ikke et eventuelt hjælpeverbum) til 
og med det sidste betonede element. Den nøjagtige afgrænsning af fokusdomæne kan være vanskeligere i mere komplekse strukturer, som fx de interrogative, men det grundlæggende princip er det samme: Alt andet lige er rytmegruppens sidste element involveret.

Ethvert fokusdomæne - simpelt eller specialiseret - er struktureret. I de to betragtede eksempler, (9) og (16), rammer fokaliseringen i alle tilfælde domænets sidste ord, der qua sin placering er betonet. Hvad mere er, synes den snævreste fokalisering også at være den, man nemmest forestiller sig. Den fører til defaultfokus, som er resultatet af defaultlæsningen. På den anden side set kan den simple fokalisering, fordi den er syntaktisk, ikke ramme en størrelse, der er mindre end et ord. Ved at kombinere disse to iagttagelser får vi følgende struktur:

(16') (robe(blanche))

for fokusdomænet (som i dette specielle tilfælde er nøjagtigt det samme som det, syntaktikerne normalt kalder "fokus").

Denne strukturering er allerede i 1971 registreret af Chomsky, som inden for rammerne af den generative grammatik har opstillet et sæt formelle regler for at gøre rede for den. I den tilgang, jeg her har plæderet for, forudsiges strukturen direkte af de generelle fokusmarkeringsregler, som er uafhængige af den særlige problematik. Disse regler vedrører først og fremmest trykkets funktion i talen: Fokalisering kan kun ramme et betonet element. Vi skal se nedenfor, at dette er en konstituerende egenskab ved specialiseret fokalisering (på fransk), og den franske lingvist Mario Rossis undersøgelser har klart vist, at det også gælder for simpel fokalisering (Rossi 1985). Dertil kommer, at markeringen af simpelt fokus, som vi har set, ikke kan angå en størrelse under ordplan. Kombinationen af disse regler forklarer, hvorfor (simpelt) fokus altid inkluderer domænets sidste ord, og vi har en forklaring på strukturen i (16'). At fokaliseringen har tendens til at ramme et lille segment snarere end et stort (dvs. at defaultfokus principielt er det mindst mulige fokus), forklares derimod af en anden type regel, som snarere er pragmatisk: Jo mindre et segment er, jo mindre præcis er dets semantiske værdi, og som følge deraf, jo mere "naturligt" er det involverede paradigme. Således forestiller man sig utvivlsomt i eksempel (16) lettere en situation, hvori det drejer sig om at vælge mellem kjoler, end en situation, hvori valget står mellem kjoler og andre ting (som altså ikke er kjoler). Som det fremgår af dette ræsonnement, bestemmes default- 
fokus i virkeligheden af flere forskellige faktorer.

Defineret på denne måde vedrører fokusdomæne fokus' form. Medens (simpelt) fokus altså syntaktisk set har ordet som mindste skydeskive, angår det semantisk set kun en del af det fokaliserede ord. Lad os tage et eksempel:

(19) C'est la robe que je veux.

Det fokaliserede ord, robe, indeholder mindst de to semer (dvs. betydningskomponenter) /beklædningsgenstand/, der er generisk, og /af formen f/, der er specifikt. Det er oplagt, at det kun er det specifikke sem, der fokaliseres i (19). Det er let at forklare. De generiske semer hjælper med til at etablere det involverede paradigme, medens de specifikke semer netop etablerer distinktioner inden for paradigmet. Helt generelt kan man tilsyneladende opstille en regel, der siger, at jo mere specifikt et sem er, jo større tilbøjelighed har det til at blive fokaliseret (jo mere tiltrækker det fokaliseringen). Defaultfokus rammer kun de mest specifikke semer. Det er derfor, lidet specifikke ord meget dårligt kan udgøre fokus:

(20) a. Dans l'armoire, les chaussures sont rangées.

b. 'Dans l'armoire, les chaussures se trouvent.

De to verber indeholder begge semet /befinde sig/, men ranger har derudover også det specifikke sem /i en vis orden/. Det er det, der gør dette verbum "fokaliserbart".

\subsection{Specialfokus}

$\mathrm{Nu}$ vi har præciseret, hvad den grundlæggende identifikationsfunktion består i, kan vi se nærmere på de yderligere specialiserede egenskaber, visse foki udviser. Lad os igen se på de sidste fire eksempler præsenteret ovenfor:

(13) (Luc est toujours malade), alors que Paul est guéri.

(14) (Pierre ne l'a pas confirmé,) il l'a affirmé.

(15) Même Paul a compris.

(16) C'est la robe blanche que j' aimerais acheter.

Disse fire ytringer indeholder specialfoki. Her kan vi skride til en yderligere underinddeling. De to første foki er umarkerede på sætningsniveau, medens de to sidste er markeret henholdsvis af adverbiet même og 
af den særlige syntaktiske struktur (kløvningen), der udpeger særlige fokusdomæner.

Som vi allerede har bemærket, er (13) og (14) eksempler på det, man sædvanligvis kalder kontrastfokus. I sin simpleste form er denne type altid umarkeret på sætningsniveau. Da den altså ikke er bundet af et fokusdomæne, er dens anvendelse fakultativ, og den kan manifestere sig hvor som helst i ytringen. Den "metalingvistiske" variant, der bruges til at korrigere eller kommentere selve brugen af de sproglige former, kan endda ramme formelle størrelser, der er mindre end ordet, som det fremgår af eksempel (14). I talt sprog er kontrastfokus altid ledsaget af stærktryk (der kan være mere eller mindre stærkt), og det lejrer sig oven på den allerede dannede struktur. Faktisk ledsages specialfokus af enhver form (altså også de bundne typer) altid af en vis accentuering. Vi vil derfor tale om fokustryk i denne forbindelse. For de sprogforskere, der definerer fokus prosodisk eksisterer kun fokus med fokustryk. Således kan fx en sætningskløvning for "prosodikerne" være uden fokus, nemlig når det, syntaktikerne kalder fokus, udtales uden stærktryk, hvilket faktisk forekommer.

Ubundet specialfokalisering kan have nogle spektakulære virkninger, når den rammer ord uden reference. I visse tilfælde, som når den rammer verbet, får man en "polariseret fokalisering" eller det tyskerne kalder et "Verum-Fokus". Denne specialfokalisering bruges til at fremhæve sandsynligheden af, at en idé, der allerede er til stede i teksten, faktisk bliver realiseret (jf. Hetland 1992), og er langt hyppigere i de germanske sprog end i fransk, hvor den næppe findes uden for spontant talesprog. Følgende er et dansk eksempel:

(21) a. Du skal ikke gøre det.

b. Du skal ikke gøre det.

Jeg overlader til læseren at fremanalysere virkningen af fokustryk på verbet i eksempel a. Man kan dog også på fransk finde (special)fokalisering af ord uden reference. (22) er et ret typisk eksempel:

(22) Paul n'a pas battu le chat avec le bâton.

Et fokustryk på pas medfører en form for ekkovirkning. Man får indtryk af, at resten af ytringen er en mere eller mindre ordret gentagelse af en allerede ytret sætning. Derved bliver nægtelsen stærkt polemisk, ja nærmest aggressiv. 
Hvad er nu relationen mellem specialfokus og simpelt fokus? Af reglen om, at enhver ytring indeholder nøjagtigt ét simpelt fokus (se ovenfor) følger direkte, at tilstedeværelsen af et specialfokus medfører, at der er to foki i en og samme ytring: et specialfokus og et simpelt fokus. Drejer det sig om et neutralt fokus, har dette imidlertid tendens til at glide i baggrunden, og når fokustryk rammer det sidste betonede ord, altså det segment, der også er forudset som neutralt fokus, bliver det neutrale fokus næsten redundant. En nærmere analyse af de fonetiske forhold afslører imidlertid, at det stadig er til stede:

(23) Ce n'est pas la réponse, ce n'est qu'une réponse.

Selv om sidste segments første stavelse får (kontrast)fokustryk, bevarer sidste stavelse sit normale tryk, hvilket ses af, at nasalvokalen forbliver lang (lange vokaler er på fransk kun mulige i trykbærende stavelser). Dette er et empirisk argument for, at det neutrale fokus overlever i (23). Dertil kommer så et teoretisk: Det kommer ud på et, om man hævder, at kontrastfokus erstatter det neutrale fokus, eller om man siger, at de to foki på samme segment er til stede samtidig. Begge analyser forudser nemlig samme interpretation. Af teoretiske grunde (Occams berømte ragekniv) er sidstnævnte analyse dog at foretrække, da den tillader os at bevare den enkle regel om, at der er netop ét simpelt fokus i enhver ytring.

Dette analyseproblem har vi ikke i forbindelse med det simple fokus i kløvninger. Det forbliver mærkbart, også selv om det kombineres med fx et kontrastfokus. Selv om der er en vis affinitet mellem kontrastfokus og kløvningsfokus, er kontrastering nemlig fundamentalt anderledes end stærk identifikation, eftersom stærk identifikation ledsages af præsuppositioner, som man aldrig finder i forbindelse med kontrastering. Derfor kan de to typer uden problem kombineres:

(24) J'ai appris que Rodrigue et Julie sont déjà arrivés.

- Non, c'est Rodrigue et Catherine qui sont déjà là.

Muligheden for kontrastfokus kan for $\emptyset$ vrigt ofte vanskeliggøre de praktiske fokusanalyser betragteligt. For så vidt som kontrastfokus ikke er markeret på sætningsniveau, vil jeg derfor se helt bort fra denne mulighed i det følgende. 


\subsection{Bundet specialfokus: Fokalisatorer}

Lad os i stedet se nærmere på de bundne specialfoki. Man har ofte kaldt de (ikke-prosodiske) størrelser, der kan markere fokus, for fokalisatorer. Det vil jeg også gøre, idet det dog skal understreges, at fokalisatorerne arbejder på sætningsniveau. De angiver altså ikke direkte fokus, men udpeger derimod et fokusdomæne. Fokalisatorer kan være morfologiske, leksikalske og syntaktiske ${ }^{10}$. Fransk har kun de to sidste typer; men mange såkaldte eksotiske sprog er rige på morfologiske fokalisatorer. Følgende eksempler er fra sproget Somali:

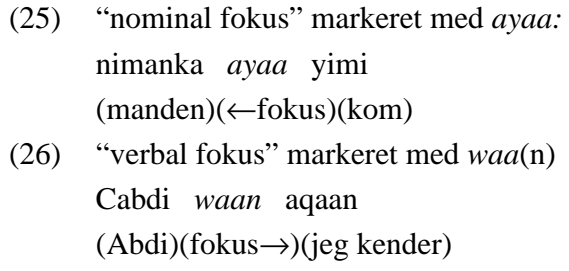

Vi har allerede set eksempler på en leksikalsk fokalisator (adverbiet même i (15)) og en syntaktisk fokalisator (sætningskløvningen i (16)). Det specialiserede formål knyttet til fokus kan variere og afhænger af den anvendte fokalisator. Især de leksikalske fokalisatorer formidler stærkt specialiserede formål. For en særlig klasse adverbier, de paradigmatiserende adverbier, som même tilhører, er netop denne fokusmarkering en central egenskab. Formålet kan variere betragteligt. Nogle er additiver, for så vidt som de angiver, at fokus skal føjes til andre af paradigmets elementer, for hvilke vi allerede ved (det er præsupponeret), at sætningen er (ville være) sand. Adverbiet aussi (i betydningen 'også') er et rent additiv, medens fx même og surtout yderligere formidler en evaluering af tilføjelsen. Andre paradigmatiserende adverbier er mere "normale" fokalisatorer i den forstand, at de har en slags kontrastfunktion, der udelukker alle andre paradigmemedlemmer. Adverbiet seulement er et sådant eksempel. Endnu andre paradigmatiserende adverbier spiller på andre akser end ' \pm integration'. Det gælder fx exactement, der går på præcisionsgraden.

En særlig type syntaktiske fokalisatorer har en speciel interesse for tekststrukturen, idet de markerer temafokus. Definerer vi tema, som

10 Det ville være naturligt og give et smukt system også at kalde fokustryk for en prosodisk/fonetisk fokalisator. I denne artikel vil jeg dog følge traditionen og undlade denne betegnelse. 
det der tales om - det er definition b. i (8) - og går ud fra, at dette normalt er ytringens første segment(er) - definition a. - fremgår det direkte af vores beskrivelse, at neutralt fokus aldrig kan ramme tema. Det neutrale fokusdomæne er jo postverbalt. Men der er intet til hinder for, at tema eller en del af tema kan underkastes specialfokalisering. Vi har allerede set eksempler på dette, nemlig (13) og (15). Der findes endda en syntaktisk bundet specialfokalisering, der er "født" tematisk:

(27) Quant à Pierre, il ne peut plus rester ici.

(28) Pierre, les gendarmes l'ont arrêté ce matin.

(29) Max, pour sa part, en était tout à fait content.

I alle tre eksempler er tema fokaliseret, for så vidt som opmærksomheden henledes på, at temaet er et (nyt) valg blandt flere mulige temaer. Denne særlige fokusvirkning føles i $\emptyset v$ vrigt endnu tydeligere i benægtede ytringer, især af typen (30), hvor man klart har indtryk af, at nægtelsen går på subjektet:

(30) Paul, lui, n'a pas battu le chat avec le bâton.

(30) viser os, at den tematiske fokalisering af subjekt i (29) ikke udelukkende skyldes pour sa part's semantiske indhold, men også hænger sammen med placeringen af denne vending. Man kan da også udskifte den med ord som lui, pourtant, heureusement osv. med fuldkommen samme virkning. Læg mærke til, at dansk ikke råder over denne syntaktiske position. Det er ikke dansk at sige fx Peter, imidlertid, kommer $i k k e$. Til gengæld har dansk sætningstryk, der, hvis det sættes på subjektet, har en lignende temafokaliseringseffekt. Faktisk oversættes (30) bedst til dansk ved ytringen Poul har ikke släet hunden med stokken, altså med stærktryk på subjekt. Det er fristende at se en sammenhæng mellem disse syntaktiske og prosodiske forskelle på de to sprog. For at vende tilbage til de franske eksempler kan man bemærke, at vendingen pour sa part takket være sin semantik bevarer samme fokusvirkning i alle syntaktiske positioner. Pour sa part er altså en leksikalsk fokalisator. At fokus måske føles stærkere med pour sa part i (29), end det ville føles med fx heureusement, skyldes sikkert, at fokus så er dobbelt markeret: leksikalsk (pga. pour sa part's betydning) og syntaktisk (pga. dette udtryks placering i sætningen). Man kan altså konkludere, at fransk har en (indskudt) position umiddelbart efter (det ubundne) subjekt, der udpeger subjektet som (specialiseret) fokusdomæne. 
I virkeligheden er der her tale om et særtilfælde af en mere generel regel. Man kan nemlig vise, at indskud ofte (på fransk) udpeger et fokusdomæne til venstre ${ }^{11}$. Følgende er et spektakulært eksempel:

(31) Paul a vendu, peut-être, sa voiture, ...

(31), der principielt er ugrammatisk, er alligevel mulig i en sammenhæng, hvor man fortsætter med at sige fx [...] parce que je suis sûr qu'il ne l'a pas prêtée.

Følgende skema resumerer de forskellige typer foki:

Den specialfokusvariant, man finder i kløvninger, udgør sammen med neutralt fokus simpelt fokus. Simpelt fokus er altid bundet af et fokusdomæne, som genereres syntaktisk, derfor er den ene kasse i skemaet tom.

\subsection{Kontrastvirkningen og tekstkohæsion}

Kan vi præcisere formålet med temafokus? For at nærme os et svar på dette spørgsmål må vi først se på fokaliseringens diskursive funktion. På grund af sin paradigmatiske egenskab indeholder fokus altid en nuance af kontrast, alene fordi det trufne valg går på det valgte element og ikke på et andet fra paradigmet. Den diskursive udvikling udnytter denne kontrastivitet. For at sætte to størrelser fra hver sin af to på hin-

11 Dette fænomen har en fonetisk forklaring. En fonetisk analyse af indskud (jf. Morel 1992) viser, at starten på et indskud ikke er angivet af en pause, som man ofte intuitivt føler, men derimod af en stærk accentuering af den sidst forudgående stavelse. Denne accentuering udløser næsten automatisk et specialfokus på det segment, der indeholder denne stavelse. 
anden følgende ytringer i forhold til hinanden er man nødt til at fokalisere hver enkelt af dem.

Når den ønskede sammenhæng er en egentlig kontrastering, kan man altid gribe til fokustryk. Som sagt er denne "fokalisator" imidlertid langt mindre anvendt på fransk end fx på de germanske sprog. Til gengæld råder fransk over andre midler til at opnå samme virkning, og de specialfokaliseringer af subjekt, vi så på ovenfor i (27) til (30), er eksempler herpå. Denne opfattelse styrkes, som vi så det, af kontrastive betragtninger. I oversættelsen af (30) erstattes det indskudte lui af et stærktryk på subjekt.

Disse iagttagelser sætter os i stand til at præcisere formålet med temafokus. Det anvendes til at indicere, at sætningen vil kunne ytres relevant $\mathrm{i}$ en kontekst, hvori tema kontrasteres (i svag forstand) med tema enten i den foregående eller i den følgende sætning. I første tilfælde, som er langt det hyppigste, kan man præcisere yderligere. Formålet er så at angive temaskift.

Temafokus er langt fra det eneste fokus, der bidrager til at skabe tekstkohæsion. Alle foki har i bund og grund (også) denne tekstuelle funktion. Den stærke identifikation i kløvninger er et andet tankevækkende eksempel. På grund af de præsuppositioner, kløvningen formidler, præsenteres den stærke identifikation her som en forventet information. I denne forstand fungerer kløvningen som svar på et (oftest implicit) spørgsmål, der - stadig i følge kløvningen selv - er stillet tidligere i teksten. Dertil kommer, at kløvningens relativsætning ekspliciterer paradigmet, identifikationen finder sted indenfor, hvilket medfører at jagten på det underforståede spørgsmål på præcis vis medvirker til kohæsionsdannelsen. Derfor er kløvninger velegnede som "reminders":

(33) Oui, comme tu sais, c'est bien Pierre qui est parti chercher maman.

eller som "identifikationskorrektører":

(34) Non, c'est Pierre qui est allé chercher maman.

\subsection{Fokus og ordstilling}

Fokus' kohæsive funktion kan hjælpe med til at forklare visse ordstillingsfænomener. Vi skal først se på et eksempel med såkaldt stilistisk inversion og derpå på sætningsadverbialernes placering. 
Hvis man af en eller anden grund (fx for at "tematisere") ønsker at foranstille syntagmet dans l'armoire i (35):

(35) Les chaussures étaient rangées dans l'armoire.

har man de to følgende muligheder:

(35) a. Dans l'armoire, les chaussures étaient rangées.

b. Dans l'armoire étaient rangées les chaussures ${ }^{12}$.

De to ytringer er imidlertid ikke helt ækvivalente, idet de typisk findes i to forskellige slags kontekster. Således er (35a.) mest velegnet i en kontrastiv sammenhæng som fx i (36):

(36) Dans l'entrée les chaussures se trouvaient dans un désordre affreux, alors que dans l'armoire elles étaient rangées.

Derimod indgår (35b.) snarere i en sammenhæng, hvor det væsentlige er, at skoene befinder sig i skabet og ikke andetsteds. I (35b.) er étaient rangées altså næsten synonymt med se trouvaient, hvorimod verbet ranger bevarer sin fulde specifikke betydning i (35a.). Denne analyse bekræftes af, at man let kan erstatte étaient rangées med se trouvaient $\mathrm{i}$ (35b.), hvorved man får:

(37) Dans l'armoire se trouvaient les chaussures.

medens denne substitution giver en dårligt acceptabel ytring i (35a.):

(38) 'Dans l'armoire, les chaussures se trouvaient.

Disse iagttagelser forudses af vores analyse af fokus. I begge eksempler befinder hovedverbet sig i det neutrale fokusdomæne; men i (35a.) - og kun i a. - er det placeret i den del af domænet, der nødvendigvis rammes af fokaliseringen pga. den interne strukturering af domænet ${ }^{13}$. Verbet fokaliseres altså altid i denne sætningsstruktur. Imidlertid har vi set, at simpelt (og dermed neutralt) fokus kun kan ramme specifikke semer. Derfor føles det underligt at afslutte en ytring med et verbum som se trouver, être o.l., der kun indeholder generiske semer. På denne måde bidrager fokusteorien til vor forståelse af de ret komplekse mekanismer, der styrer fænomenet stilistisk inversion.

Et andet ordstillingsproblem, der har voldt forskerne hovedpine, og hvor fokusteorien kan spille en rolle, er sætningsadverbialernes place-

12 Her taler man ofte om stilistisk inversion.

13 Jf. analysen af fokusdomænets struktur eksemplificeret i (16'). 
ring. Det er almindeligt anerkendt, at sætningsadverbialerne på fransk kan stå mange forskellige steder i sætningen. I en simpel struktur med sammensat verbum er der principielt de fem muligheder angivet i (39):

(39) $\underline{1 .(,)}$ Subjekt, …, Aux $\underline{3}$. Participium (4.) Objekt, $\underline{5 .}$.

Sætningen i (40) er et eksempel på denne struktur:

(40) $\underline{1 .(,)}$ Paul, 2., a $\underline{3}$. vendu (4.) sa voiture, $\underline{5 .}$.

Alle muligheder fører dog ikke til lige vellykkede sætninger, nogle kræver kommaer, og - måske allervigtigst - valget af position er aldrig frit, men afhænger af den større sammenhæng ytringen skal indgå i. For en ikke frankofon er det meget vanskeligt at vælge den rette placering af adverbialet, og han får ingen hjælp af grammatikkerne, der stort set intet har at sige om problemet. Jeg skal her skitsere, hvorledes fokusteorien kan bringe nogle elementer til en forklaring ${ }^{14}$.

Sætningsadverbialer er altid underkastet ytringsoperationen monstration, jf. 1.2. De anvendes til at bringe kommentarer - enten til selve ytringsprocessen som i Franchement, Paul est bête, hvor det er selve det at ytre 'Paul est bête', der betegnes som 'franc', eller til det, der siges, som i Heureusement que Paul a guéri, hvor det lykkelige er, at Poul er blevet rask. Holder vi os til sidste type, angår kommentaren altså informationen, og da valget af fokus er den centrale del af denne, angår kommentaren specielt valget af fokus. Man kan nu vise, at denne sammenhæng mellem fokus og adverbial er så væsentlig, at placeringen af adverbialet ligefrem tjener til at udpege fokus. Dette sker efter følgende regler, der følger af nogle mere generelle semantiske og prosodiske regler:

- Udtales adverbialet med normal glidende intonation, udpeger det strengen umiddelbart til højre og strækkende sig til næste intonationsbrud som fokusdomæne ${ }^{15}$.

- Udtales adverbialet med "parentesintonation" (hvilket typisk angives ved en omkransning med kommaer), udpeger det den umiddelbart forudgående konstituent som fokusdomæne.

Ser vi nu igen på den skematiske struktur i (39), fremgår det, at et adverbial i position 2 . fokaliserer subjekt, medens et adverbial i posi-

14 Se Nølke (1994: $§$ V.6.4.3.) for en grundigere analyse.

15 Dette er blot et specialtilfælde af den generelle regel, jeg nævnte i 2.5., og som blev uddybet i note 11 . 


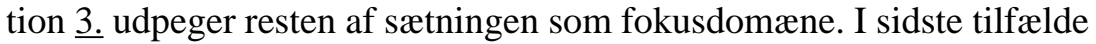
er der totalt sammenfald med det normale neutrale fokusdomæne, og det er fristende at se dette sammenfald som en forklaring på, at $\underline{\text { 3. fak- }}$ tisk er normalplaceringen for sætningsadverbialer.

Vi kan nu se nærmere på, hvad der spiller ind på det konkrete valg af placering af sætningsadverbialer, franskmænd foretager. Lad os se nærmere på eksemplerne i (41), der illustrerer (de fire normale af) mulighederne i skema (39):

(41) a. Peut-être que Paul a vendu sa voiture.

b. Paul, peut-être, a vendu sa voiture.

c. Paul a peut-être vendu sa voiture.

d. Paul a vendu sa voiture, peut-être.

Ifølge ovenstående regel skulle de fire forskellige placeringer af sætningsadverbialet peut-être svare til fire forskellige fokaliseringsvirkninger som angivet ved understregning i eksemplerne. På grund af fokus' rolle for tekstkohæsionen kan vi undersøge dette ved at anbringe sætningerne i forskellige kontekster. Lad os betragte følgende tre mulige fortsættelser:

(42) a. (..), mais je n'en suis pas sûr.

b. (...), mais Marie n'a pas vendu la sienne ; là j'en suis sûr.

c. (...), mais il n'a pas vendu sa maison ; là j'en suis sûr.

Alle fire sætninger i (41) tillader alle tre tænkte fortsættelser; men ikke alle kombinationer er lige vellykkede. En simpel intuitiv analyse, der i $\emptyset$ vrigt støttes af kvantitative undersøgelser på et større korpus, viser, at afsender har stærke præferencer. Forudser han (42a.), har han tendens til at vælge (41a.), forudser han (42b.), vælger han snarere (41b.) - eller evt. (41a.) eller (41c.), men med fokustryk på Paul - forudser han endelig (42c.), vælger han (41c.) eller (41d.).

Som det fremgår, forklares denne kombinatorik umiddelbart af den indflydelse, fokaliseringen har på tekstkohæsionen, for i hver enkelt foretrukne kombination kontrasteres de fokaliserede segmenter i de to ytringer. At der ved valget af placering for adverbialet er tale om tendenser (om end stærke) snarere end om egentlige regler, passer også godt med, at den foreslåede forklaring refererer til ytringsniveau, hvor "uheldige" valg kun medfører "uheldige", men ikke ugrammatiske 
ytringer. Alt tyder således på, at vi er på rette spor. Der findes endda nogle marginale ytringer, som yderligere understøtter analysen:

(43) Paul a vendu peut-être sa voiture.

Jeg har med vilje undladt tegnsætning, da flere intonationsmønstre er mulige i (43). Adverbialet står her i skema (39)s position 4 .. Denne placering er syntaktisk uheldig uden dog at være helt umulig. Position $\underline{4}$. er nemlig midt i sætningskernen, hvor størrelser underkastet monstration kun vanskeligt kan placeres, fordi de ikke tager del i konstruktionen af det propositionelle indhold, så afsender må have en specielt god grund for at vælge denne placering. Han må have et præcist formål. Hvad kan det være? De to tænkte fortsættelser i (44) leder os på sporet:

(44) a. Paul a vendu, peut-être, sa voiture; puisqu'il est hors de doute qu'il ne l'a pas prêtée.

b. Paul a vendu, peut-être sa voiture ; mais certainement pas sa maison.

Peut-être udpeger to forskellige fokusdomæner i disse eksempler pga. de forskellige intonationsmønstre (angivet ved kommatering). I (44a.) udgøres domænet af verbet, og denne sætning er da også kun mulig i en sammenhæng, hvori handlingen, verbet angiver, kontrasteres med en anden handling. I (44b.) er det derimod sa voiture, der fokaliseres, og denne ytring er da faktisk også helt udelukket med mindre, den netop følges umiddelbart op af en præcisering af, hvad sa voiture skal kontrasteres med.

\section{Informationscocktailen}

Afsender råder over en palet af muligheder, som han udnytter mere eller mindre bevidst til at få sit budskab igennem på netop den måde, han $\emptyset n s k e r$ det. Ganske vist er det jo interpretationsprocessen, der i den sidste ende er ansvarlig for budskabets endelige udformning, men afsender kan ved hjælp af en række forskellige sproglige virkemidler $\mathrm{i}$ vidt omfang styre denne proces. Vi skal her kort se på, hvilke muligheder og $u$ muligheder der er for at blande forskellige informationstyper sammen til en "informationscocktail".

Jeg har ovenfor plæderet for, at ytringen på en og samme tid kan kommunikere flere forskellige informationstyper, typisk manifesteret ved binære par, der udnytter den helt fundamentale skelnen mellem 
baggrund og forgrund (jf. (8)). Det er netop dette forhold, der har voldt så mange problemer for lingvister, som gerne har villet se én strukturering i forgrunds- og baggrundsinformation. Det vrimler imidlertid med eksempler på, at man kan kombinere baggrundsinformation af en type med forgrundsinformation af en anden. Vi har allerede set, at der intet er til hinder for, at fx tema (som jo er af typen baggrundsinformation) fokaliseres og i denne forstand bringes i forgrunden.

Der er dog visse begrænsninger på kombinationsmulighederne. Man kan vise, at præsupponeret indhold præsenteres som ramme for kommunikationen. Præsuppositioner tjener derfor kommunikations $ø$ konomiske forhold. De kan støtte sig på baggrundsviden, situation osv. og præsenteres ofte som baggrund til lettere forståelse af den væsentlige information. Til gengæld kan de så netop ikke bruges til at præsentere væsentlig information. Pakker man alligevel information, der for sammenhængen kan være væsentlig - fx fordi den er ny for modtager, eller fordi han ikke er enig i den - ind i præsuppositioner, kan det få en manipulerende virkning.

Præsuppositioner er en særlig (stærk) form for gammel eller kendt information. Information kan være kendt af flere grunde. Den kan være kendt fra en fælles sociolingvistisk baggrund (enhver franskmand ved, hvem der er Frankrigs præsident), fra den aktuelle situation (vi ser og hører det samme) eller fra den foregående tekst (koteksten). Mere og mere gammel viden opstår fra den sidste kilde, efterhånden som teksten skrider frem, og der kan være brug for at præsentere kendt information bl.a for at minde om den. Dertil tjener bl.a. mange typer bisætninger:

(45) Det er klart, han ikke kan komme.

I (45) præsenteres det, at han ikke kan komme, som kendt, selv om det naturligvis ikke i praksis behøver være det. Læg mærke til, at dette indhold ikke er præsupponeret, hvilket afsløres ved, at man sagtens kan følge (45) op med en ytring som Det troede jeg, du vidste.

En afgørende forskel mellem præsupponeret og poneret (ikkepræsupponeret) gammel viden er i øvrigt, at præsuppositioner aldrig kan fokaliseres. Selvfølgelig kan afsender vælge at fokalisere fælles baggrundsviden; men så prasenteres den ikke længere som præsupponeret. Et sådant valg vil altid have en særlig effekt og udløse inferenser. At gammel information i al almindelighed sagtens kan fokaliseres, er det let at finde eksempler på: 
(46) Peter er jo ikke særlig klog.

Partiklen jo angiver, at hele indholdet er kendt. Alligevel er saerlig klog fokus.

Man har ikke ganske frit valg mht., om man vil præsentere faktisk (principielt) kendt information som gammel eller ny. Det afhænger også af en faktor som, hvor præsent den er. Vil man gentage noget, der lige er nævnt, må man præsentere det som kendt information; men man kan godt alligevel fokalisere det. Hvis man derimod præsenterer det som fokaliseret, ny information, bliver modtagers reaktion: "Men det ved jeg da godt!". Dette trick kan naturligvis bruges til at provokere inferenser, for modtager vil formodentlig reagere med "Hvorfor fortæller han mig noget, han godt ved, jeg ved?".

\section{Konklusion}

Hvilke informationscocktails der kan blandes og hvilke ikke, var nok et nærmere studium værd. Det har dog her blot været mit formål at introducere til dette spændende og trods mange års arbejde endnu ret uopdyrkede område af lingvistikken. Siden oldtiden har man studeret, hvorledes man bedst formidler information set i forhold til, hvilket formål man har, og utallige er de studier, der har undersøgt, hvilken rolle sproget spiller. Alligevel står der meget tilbage at gøre.

Jeg har forsøgt at vise, at man med fordel bør opfatte informationsstrukturen som en kompleks størrelse, der opstår ved en sammensmeltning af en række enklere, ofte binære strukturer. Disse enklere strukturer bør så først analyseres hver for sig, hvorefter man kan undersøge deres kombinationsmuligheder. Helt i ånd med hvad jeg har plæderet for andetsteds (Nølke 1994), synes en modulær tilgang altså at åbne for nye veje til en bedre forståelse af de muligheder, sproget giver os for at formidle de informationer, vi ønsker at bringe videre.

Det er overordentlig vigtigt for den bevidste sprogbruger at være opmærksom på, hvilke muligheder sproget giver ham, og hvilke begrænsninger det påtvinger ham. Ønsker han at få sit budskab igennem, må han lære, hvilke ingredienser han kan bruge sammen for at mixe den mest hensigtsmæssige informationscocktail ${ }^{16}$.

16 Jeg er Annelise Schnell stor tak skyldig for en række kommentarer, hun er kommet med efter læsning af en tidligere version af denne artikel. 


\section{Bibliografi}

Ammann, H. (1925): Die Menschliche Rede. Lahr i B.

Chomsky, Noam (1971): «Deep Structure, surface structure, and semantic interpretation». In: D.D. Steinberg \& L.A. Jakobovits (eds.): Semantics. Cambridge University Press. (183-216).

Ducrot, Oswald (1980): «Texte et énonciation». In: Ducrot et al.: Les mots du discours. Paris: Les éditions de minuit. (7-56).

Hetland, Jorunn (1992): «VERUM-Fokus : Fakten, Hypothesen, Fragen und nochmals Fragen». In: Sprache und Pragmatik 25 (Lund). (11-27).

Kronning, Hans (1990): «Modalité et diachronie : du déontique à l'épistémique. L'évolution sémantique de debere/devoir». In: Actes du XIe Congrès des Romanistes Scandinaves. Trondheim : L'Université de Trondheim. (301-312).

Kronning, Hans (1993): «Modalité et réorganisation énonciative de la phrase». In: Actes du XX $X^{e}$ Congrès International de Linguistique et de Philologie Romanes, Zürich, 6-11 avril 1992. (à paraître).

Morel, Mary-Annick (1992): «Intonation et thématisation». In: Information Grammaticale.

Nølke, Henning (1983): «Quelques réflexions sur la structure sémantique des phrases clivées en français moderne». In: Modèles linguistiques V. (117-140).

Nølke, Henning (1992): «Ne ... pas : Négation descriptive ou polémique ? Contraintes formelles sur son interprétation». In: Langue Française 94 (48-67).

Nølke, Henning (1994): Linguistique modulaire : de la forme au sens. Louvain: Peeters.

Récanati, François (1979): La transparence et l'énonciation. Seuil.

Rossi, Mario (1985): «L'intonation et l'organisation de l'énoncé». In: Phonetica 42. (135-153).

Vikner, Carl (1972): «Quelques réflexions sur les phrases clivées en français moderne». In : Actes du 5ième Congrès des Romanistes Scandinaves. Turku. (221-235).

Wittgenstein, Ludwig (1961): Tractatus Logico-philosophicus, London : Routledge \& Kegan Paul. (Première édition allemande. In: Annalen der Naturphilosophie, 1921). 
